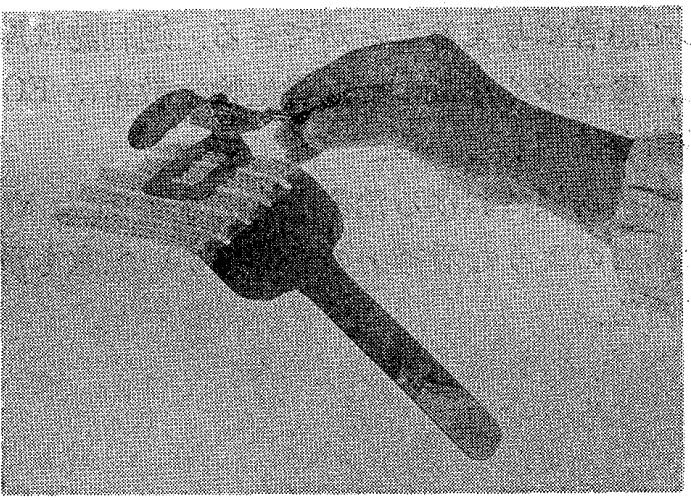

写真1

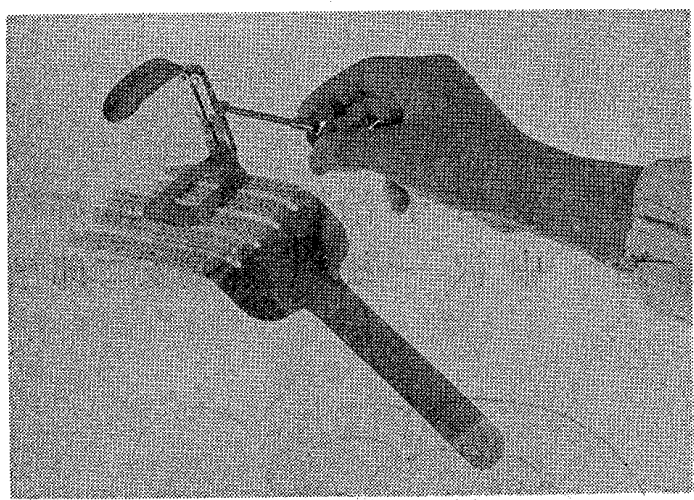

写真2

写真 1 は手の形をした鈎と縮めた状態のデバ イダーである。

写真 2 はスピンドルを回してデバイダーを伸 ばしたところを示す。

写真 3 は胆のう結石症の術中写真で手の形を した鈎とデバイダーを装着じたところである。

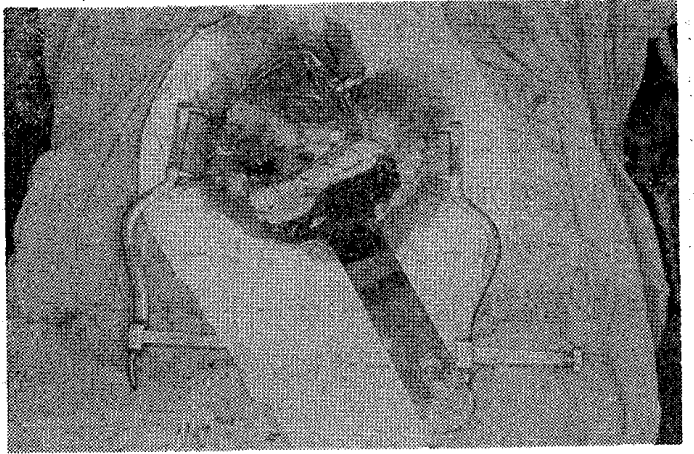

写真 3

以後の胆のら剔出操作は従来の方法と同じで 総胆管切開術も容易にできる。この手の形をし た鈎とデバイダーを用いた手術中，腸管や大網 が手術野に脱出して困ったことはなく、鈎がず れたこともないこの開創銁を用いて，これま でに岩手医大第 1 外科ならびに関連病院におい て約 140 症例の胆道手術を行った. 大部分の症 例は何事もなく，手術を終了し得たが；初期の 頃関連病院に括いて1例だけ，この鈎をかける と血圧が低下するといら症例が経験された。こ れは恐らく鈎が下大静脉か門脉を圧迫するため であろらと想像されたので, 内側の 2 本の指を 更に短くしたところ，その後このような血圧低 下はみられなくなった。

この開創鈎は東京村中医療器株で入手するこ とができる.

\title{
26. 手術用縫合糸の物理特性に関する検討
}

\section{研究目的}

ディスポーザブル手術用縫合系においても， 近年 ${ }^{60} \mathrm{Cor}$ 線照射滅菌が広く利用されている が, 縫合糸のすべり, 強度, 伸度, 弾性等の物 理的特性に対する照射線量の影響と，それらの 照射後の経時変化について; 検討したので報告

*，日腸工業(梸試験研究室

*2 東京大学中央手術部
鈴木邦重*：小林寛伊*2 都築正和*2

\section{する.}

\section{方 法}

電子管式引張り圧縮試験機（ストログラフ R 東洋精機) を用い，多办け上の摩擦係数 $\mathrm{f}$ の測 定，結び目の安全性試験(Knot Security Test) 強伸度試験および曲げ試験 (Bending Test) を 行った。 $\mathrm{f}$ 值の測定は図 1 左のように, 同一種 類の 2 本の采を $90^{\circ}$ の角度にからげ，つまり系 は180功らみついているが，連続的に張力を 
加え, 系がすべうてい:く際の極大点を計測し, 途中安定している一定区間内の平均を求め, 10 回の測定からハーマンの式により算出した。ク ロスヘッドスピードは $10 \mathrm{~mm} /$ 分, 試料には, 自社にて編み上げたブレイドシルク USP 1-0 飞, 濃度を段階的に変えてシリコーンコーティ ングしたものを用い, 各種照射線量について照 射後 8 日目, 57 日目の值を測定した。結び目の 安全性試験は，糸がすべらず結び目で切れる のに要する男結びの回数を測定するもので， 值の測定と同様の試料および照射線量を用い， クロスヘッドスピート $5 \mathrm{~mm} /$ 分に拉いて, 照射 後 8 日目，64日目の值を測定した。 また強度試 験はクロスヘッドスピート $300 \mathrm{~mm} /$ 分, 試料に ブレイドシルク，ブレイトホポリェステル，モ， フィラメントナイロン各種 USP 1-0 を用いて 2 種類行った。 1 つは 2.5Mrad 10 回までのく り返乙照射に和汀る結節強度を測定するもの， も5 1 種類は伸度試験と同時に行々，照射線量 0 から， 3 Mrad‡でについて，照射後 1 週間， 1 力月目, 3 力月目注扝ける直線強度 (引張り 強度）抢よび伸度を調心るるのである。なお伸 度試験は試長 $130 \mathrm{~mm}$ における相対伸度を求め た，次に縫合系の曲げ剛性を調ベるベンディン グテストは図1右のような装置を使用し，照射 線量 0 から $3 \mathrm{Mrad,クロスヘッドスピード} 10$ $\mathrm{mm} /$ 分強伸度試験と同様の試料を用い，照射 後 5 日目; 132日目について測定した。なお 60 Cor線照射は，固定方式で行い，目標值と実際 の照射線量を比較するために，パースペックス ドシメータを用いて，吸光度測定により線量測 定を行った。

\section{FRICTION TEST}

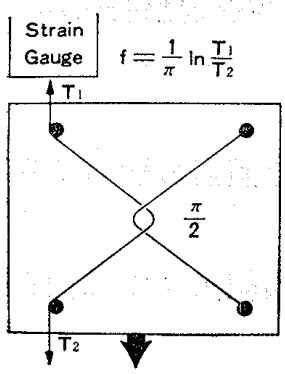

曲げ試験Bending Test

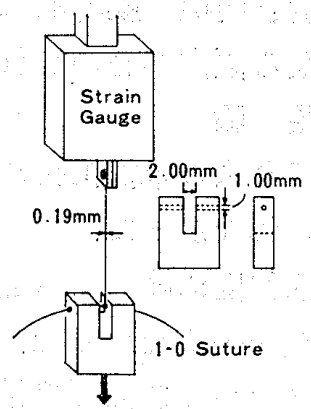

図1

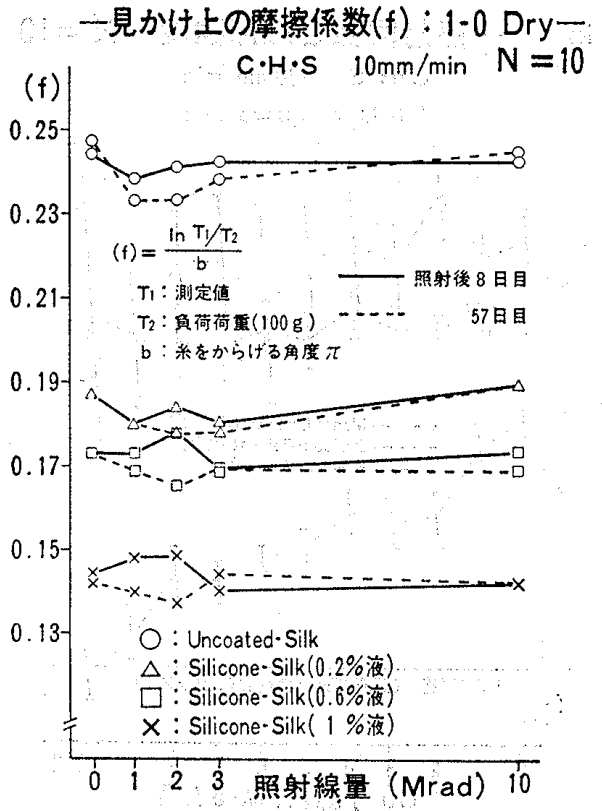

図 2

\section{成績および総括}

実際の照射線量と目標值との詿差は，低線量 域でも士 $7 \%$ 程度；高線量域では土 $1 \%$ 程度以 内の差に招さまっていた。実験の結果は目標值 で示した。図 2 注照射線量 $0,1,2,3,10 \mathrm{Mrad}$ における $\mathrm{f}$ 值の測定結果であるが，いずれの加 工状態に打いても照射線量の差による違い，経 時変化汇明らかな差はみられず，コーティング による摩擦抵抗の違いだけが表われている。な お重量測定による定量結果では, 処理液の濃度 増加に対する縫合糸のシリコーンの実際の付着 量についてはほぼ直線的な増加傾向を示し，相 関係数 0.9 以上という值を示していた，今回の 実験においては，系に対して処理液の濃度の50 \%近い重量であった。表1は結び目の安全性の

表 1

$$
\begin{aligned}
& \text { - Knot Security Test: Dry-N }=10 \\
& \text { Braided-Silk } 1-0 \quad \text { C.H.S } 5 \mathrm{~mm} / \mathrm{min}
\end{aligned}
$$

\begin{tabular}{|c|c|c|c|c|c|c|c|c|c|c|}
\hline 照射線量(Mrad) & & 0 & & 1 & 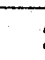 & $?$ & 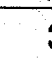 & 3 & 10 & \\
\hline 照射後日数(day) & 8 & 64 & 8 & 64 & 8 & 64 & 8 & 64 & 8 & 64 \\
\hline 證加 I & 2 & 2 & 2 & 2 & 2 & 2 & 2 & 2 & 2 & 2 \\
\hline $\begin{array}{l}\text { Silicone } \\
0.2 \% \text { 液 }\end{array}$ & 3 & 3 & 3 & 3 & 3 & 3 & 3 & 3 & 3 & 3 \\
\hline $\begin{array}{l}\text { Silicone } \\
0.6 \% \text { 液 }\end{array}$ & 4 & 4 & 4 & 4 & 4 & 4 & 4 & 4 & 4 & 4 \\
\hline $\begin{array}{c}\text { Silicone } \\
1 \% \text { 液 }\end{array}$ & 5 & 5 & 5 & 5 & 5 & 5 & 5 & 5 & 5 & 5 \\
\hline
\end{tabular}
〈安全な結びの回数〉 Square knot 
医器学 Vol. 51, Suppl. (1981)

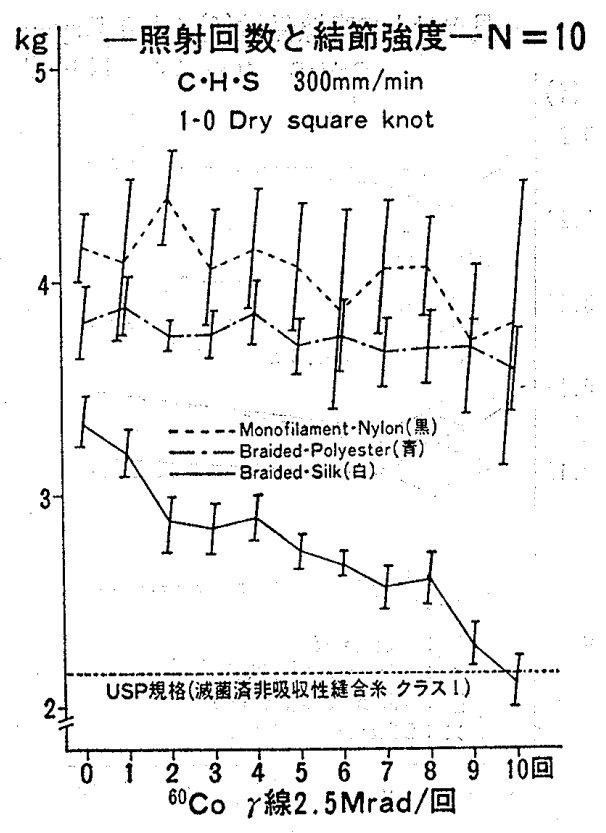

図3

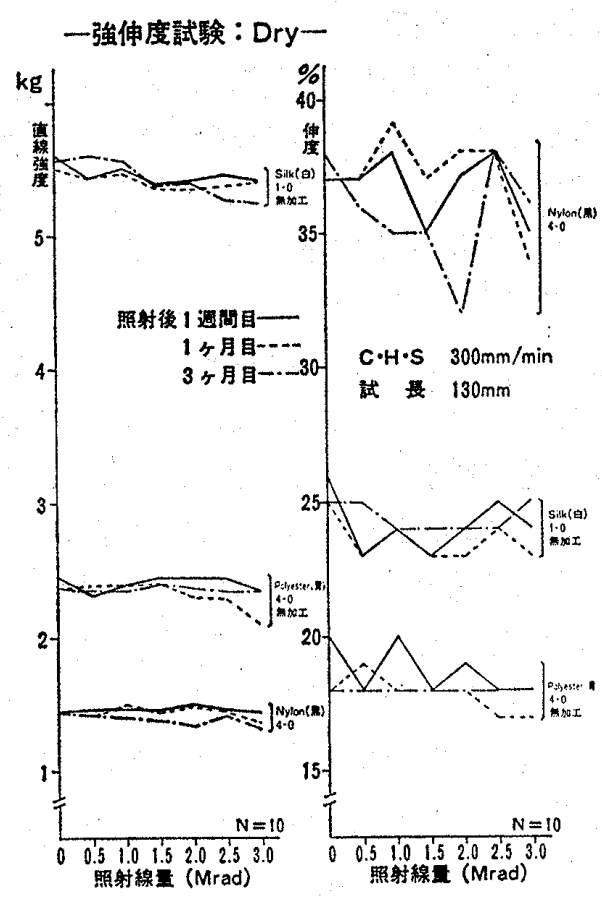

図 4

測定結果で，コーティング処理の程度が進むに 従って，縫合部位を保持するための必要な結び の回数は顕著に増加しているが，照射線量と照 射後日数が結び目の安全性に与える影響はみら れなかった。図 3 はくり返し照射における各種 縫合糸の結節強度を示したものだが, 動物性タ ンパク質であるシルクは, 放射線の影響を強く 受け10回照射ではUSP規格を下まわっている. ポリエステルとナイロンの合成繊維では, 縫合

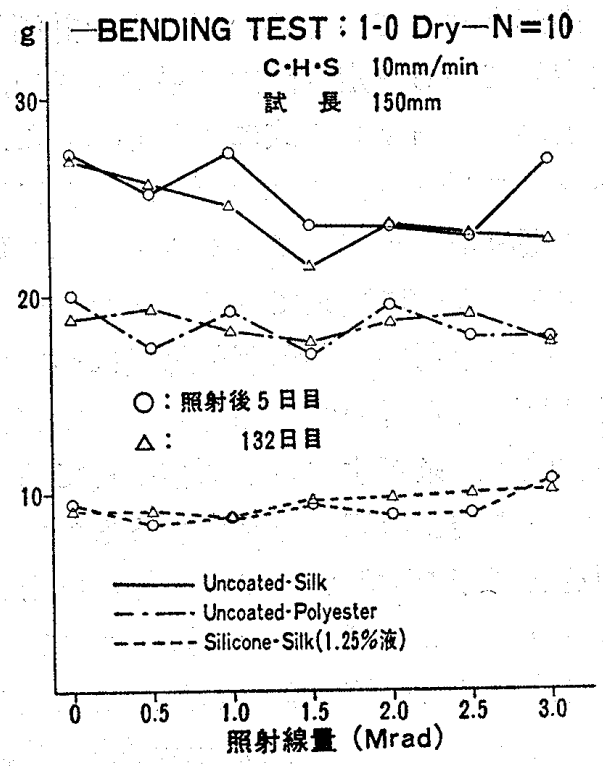

図 5

夈の染色剤が強、影響を受け，4回照射程度で 明らかに変色してしまったが，強度はごくわず かしか減少しなかった。ナイロン、、ホリエステ ルの優れた放射線抵抗性が示されている．図 4 は直線強度および伸度試験の結果である。コー ティングなしのシルクおよびポリエステルでは 強度，伸度ともに明らかな経時変化はみられな い.モノフィラメントナイロンは, 強度では非 常に安定しているが，伸度に扔いては大きなバ ラツキをみせ，乙かも経時的に多少硬くなり， 伸びが小さくなる傾向が表われている. 今後さ らに検討を要するむのと思われる。図 5 は各種 縫合糸の曲げ剛性を示したものである.コーテ ィングなしのシルク $1.25 \%$ 液で処理したシリコ ーンシルクコーティングなしのポリエステル, いずれも通常の減菌線量域では明らかな差はみ られない。なおシリコーンの処理液の濃度差に よる違いは確認されなかった。またモノフィラ メントナイロンについては，バラッキが大きく 伸度之同様, 継時的にみて, 照射後縫合糸が硬 くなる傾向が認められた。

\section{結 論}

・縫合糸の摩擦抵抗に関しては照射の影響はみ られなかった。

・強伸度に関しても通常の滅菌線量域では明ら かな差はなかった。

・伸度および曲げ剛性においてナイロンに多少 の経時変化があり硬くなる傾向がみられた。 
一辖合系に対する着色, 染料の脱色は $10 \mathrm{Mrad}$ 程度から強くあらわれた。

・全体的にみてこれら 3 種の觡合系に関しては 通常の滅菌線量域では縫合系の物性に, ほと んど影響はないものと思われる。

・今後ディスポーザブル縫合糸の有効期限程度 の経時変化を追求すべきであると考える.

(この実験を進めるにあたり放射線照射にご協 カくださったラジエ工業侏に対し感謝の意を表 わす)

\section{文 献}

1）佐藤健二他：療品の放射線滅菌ＩI 絹編糸縫合
糸の放射線照射ならびにシリコーングラプト縫 合系の特性, 衛生化学, $13: 281 \sim 284,1967$

2）佐藤健二他：療品の放射線滅菌IV 各種縫合系 の張力におよぼす放射線の影響衛生化学， 14 ： $225 \sim 227,1968$

3）佐藤健二他：療品の放射線滅菌VII $r$ 線照射絹 縫合系の物理化学的性質について, 医器誌, 40 : 718 722, 1970

4）小林寬伊 : 縫合材料, 外科 Mook No. 4 縫合 之吻合 : 1 14，1978

5) Herrmann, J. B : Tensile strength and knot security of surgical suture materials Am. Surg. $37: 209 \sim 217,1971$

\section{7. ミシンの原理による手術用縫合器（第 2 報）}

横山正義* 柳沢 正敏* 河村 剛 史* 長 柄 ${ }^{*}$ 英罗* 和 田寿郎* 野本玲司*2 江口保賢*2

\section{I 研究目的}

針と糸は外科医の必需品であり，持針器には さんだ針をらまくはこび，それについている㫧 を手際よく処理すると名外科医といわれる。

針と糸で縫合・結紫する方法は確実である が，古典的，原始的である．医学をとりまく周 辺科学技術の進歩の中で，外科手技は多少，進 歩にとり残された分野である。あくまでも外科 医の手によるメスと鋏が謳歌されている。しか しょうやく各種自動縫合器・マイクロサージャ リー，凍結手術などが臨床使用されはじめ，新 しい外科が誕生しよらとしている。

われわれはこれまで 3 年間，ミシンの原理を 応用した縫合器を試作治験し，改良を重衫てい る. 外科的縫合を迅速確実に行うために，クリ ップ法, ペッツ法, 接着法などがすでに使用さ れているが，われわれのミシン式縫合器も手術 を迅速，確実行うためのものである。われわ れの知り得る限り, 手術用の自動式ミシン縫合

* 東京女子医科大学胸部外科

*2 蛇の目ミシン工業㻝技研
器は世界最初のものである.

\section{II 原 理}

針の先端に小孔をあけ，ここに糸を通してお く, 持針器で組織を一針縫って, 針の先端が対 側に出たところで，別の系をここにくぐらせる （図 1 B)）。この糸をくぐらせる原理がミシンの 方法である、シャトルと呼ばれる米粒大のもの
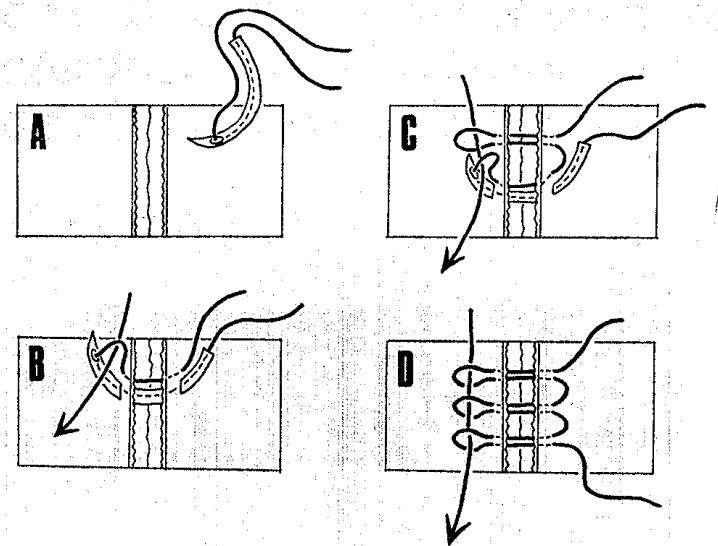

図 1 ミシン式縫合器の原理 針の先に糸をつけ, 針の先端が組織か ら出たところで, 別の糸を通す (B). この操作を連続しで縫合を行ら (C) 縫合が完成したシェーマを示す(D) 